\title{
A Universal Reversible Gate Architecture for Designing N-Bit Comparator Structure in Quantum-dot Cellular Automata
}

\author{
Bandan Kumar Bhoi ${ }^{1 *}$, Neeraj Kumar Misra ${ }^{2}$ and Manoranjan Pradhan ${ }^{3}$ \\ ${ }^{1,3}$ Department of Electronics and Telecommunication, VSSUT, \\ Burla, 768018, India \\ ${ }^{2}$ Department of Electronics Engineering, Institute of Engineering and \\ Technology, Lucknow, India \\ bkbhoi_etc@vssut.ac.in ${ }^{1}$
}

\begin{abstract}
Logic computing around quantum-dot cellular automata (QCA) has emerging area of high-speed nanoelectronics. We implemented the synthesis of the reversible comparator circuit in QCA regime that employs minimum primitives results. This paper presents a universal reversible quantum-dot cellular automata gate (URQG) and its implementation in QCA technology. The efficiency of the proposed gate in designing reversible circuits is validated by implementing the QCA standard benchmark Boolean functions. We also synthesize n-bit comparator, where proposed URQG and existing Feynman gates are cascaded together. Finally, in a QCA paradigm, we designed layout for the 1-bit and 2-bit comparators, and prove the better primitives results over existing layouts. Synthesis results indicate that the proposed 1-bit reversible comparator has achieved $75 \%$ improvement in delay and 95\% improvement in quantum cost compared to existing design. The proposed gate currently aims the testability world such as cell deposition and $H D L Q$ that test suite. The authors also show the energy dissipation results for existing benchmark reversible gates introduced in state-of-art technology and URQG gate that proposed herewith. QCADesigner tool is used to design and verify the functionality of the proposed designs. QCAPro tool is used for energy dissipation analysis of the proposed gate.
\end{abstract}

Keywords: Logic gate; Reversible logic; Quantum-dot cellular automata; Faulttolerant; $H D L Q$

\section{Introduction}

In VLSI circuits we do feel the challenge to further scale down the transistor size and to decrease the power consumption [1]. The increases in the number of transistor in a chip are often driven by increased density and degrade the performance. Computation is involved by quantum gates in which no information loss. Reversible logic finds many applications in the era of quantum computing [2]. Bennett demonstrates that no energy dissipation is possible only if a circuit involved reversible gates [3].

The existing CMOS has been under constraints by the growing QCA technology as consider to high-speed operating frequency and low power are involved [4]. The cost and complexity of a QCA design are particularly affected by the cell count, area, and latency. Thus a great deal of forced the layout consideration has been developed for optimizing the complexity and better computation speed [5].

In the work, the synthesis of a reversible comparator using QCA technique is proposed. It would be important if the primitive's results used for layout design would be optimal. Existing comparator based on conventional logic based can still provide the design

Received (June 13, 2017), Review Result (August 31, 2017), Accepted (September 12, 2017) 
engineer with enough freedom to synthesize reversible logic design to best meet the energy free requirements of a specific application [6]. The reasons are, once there is designed by reversible gates in a circuit there must be quantum gates to compute the quantum information [7]. The circuit cost is determined by the figure of merits rather than by size order of gates considerations. The figure of merits is deal with the quantum cost, garbage output, ancilla inputs and gate count $[8,9]$. There is few number of research works on reversible comparator layout in QCA with provable better primitive's results. Although the reversible comparator in QCA concept is presented in [10,11] to used coplanar approach to checking the workability. This paper targets the QCA comparator circuit which can be implemented without crossover.

The major contributions of this work are summarized as follows:

1. A new gate named as universal reversible QCA gate (URQG) is proposed. It is a $3 \times 3$ gate that realizes 13 standard functions with optimal gate count.

2. The URQG gate is compared with the existing reversible gates using standard Boolean equations. The proposed gate outperforms the existing gates in terms of design cost and testing overhead.

3. Using the QCAPro tool, energy dissipation analysis is performed for the proposed gate.

4. Hardware description language for QCA (HDLQ) Verilog library is used to measure the fault tolerance attribute of the proposed gate.

5. A novel architecture of the n-bit reversible comparator structure is designed.

This paper is organized as follows. Section 2 describes the background of the QCA technology. Section 3 introduces the proposed model, and evaluates the performance of the proposed reversible gate. New efficient reversible comparator architecture is detailed in Section 4. Comparison results are illustrated in Section 5. Section 6 concludes the paper.

\section{Background Study}

The QCA is an emerging technology in which the logic states are not stored as voltage levels, but rather as the position of the individual electrons [12,13]. A QCA cell can be viewed as a set of four "dots" that are placed at the corner of a square. A quantum dot is the location of the cell in which a charge can be localized. The cell contains two extra mobile electrons, which can quantum mechanically tunnel between the dots. Owing to Coulomb repulsion, in the absence of external electrostatic, the electrons are forced to the corner positions to maximize their separation. As shown in Figure 1 $a$, the QCA cell represents binary 1 and binary 0 configurations for the $\mathrm{P}=+1$ and $\mathrm{P}=-1$ polarization values, respectively.

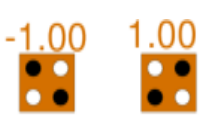

(a)

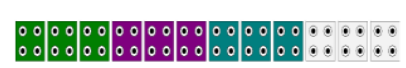

(b)

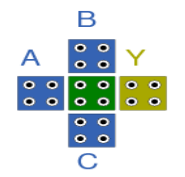

(c)

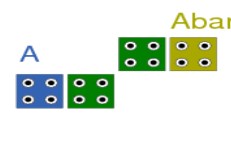

(d)

\section{Figure 1. QCA Basics (a) QCA Cell (b) Binary Wire (c) Majority Voter (d) Inverter}

The QCA operates by the Columbic interaction that connects the state of one cell to that of its neighbors, unlike the conventional logic circuits in which the information is transferred by electrical current. Figure $1 b$ shows a binary wire with four-phase clock zones. In the binary wire, a signal propagates from the input to the output owing to the Columbic interactions between the cells. In a CMOS-based 
system, timing is controlled by a reference signal (i.e., a clock) and is mostly required for sequential circuits. However, timing in the QCA is necessary for both combinational and sequential circuits and is accomplished by clocking in four distinct periodic phases. The clocking provides power gains in the QCA as well as the control of information flow between the cells. Various types of QCA devices can be constructed using different physical cell arrangements. The two basic logic gates in the QCA are the majority voter and the inverter. The logic function of the majority voter is $\mathrm{M}(\mathrm{A}, \mathrm{B}, \mathrm{C})=\mathrm{AB}+\mathrm{AC}+\mathrm{BC}$, where $\mathrm{A}, \mathrm{B}$, and $\mathrm{C}$ are the three inputs. The majority voter can be realized using 5 QCA cells, as shown in Figure $1 c$. Further, AND, OR logic functions can be implemented by the majority voter by setting an input (control input) permanently to a " 0 " or " 1 " value. The inverter is shown in Figure $1 d$, where displacements of $45^{\circ}$ in the two lines of the merging cells produce a complementary action of the input signals.

\section{New Reversible URQG Gate}

A $3 \times 3$ reversible gate named as URQG is designed in this section and is drawn in Figure 2a. The reversible truth table is listed in Table 1. Here it is proved that bijective mapping between inputs and outputs, hence it reversible. In focus to reversibility given the outputs logic P, Q, R the inputs A, B, C can be computed. The reversible URQG gate is a universal and implements 13 standard functions which are presented in Table 2. The QCA layout of the proposed URQG gate is illustrated in Figure 2b. It requires a total of six majority voters and four inverters. The present work is based on a four-phase clocking scheme, which is utilized in all the QCA circuits. All four clock zones are employed in this QCA layout.

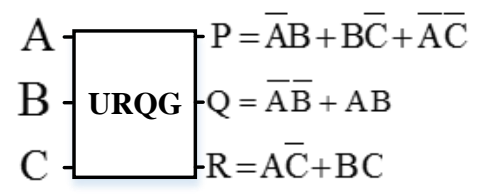

(a)

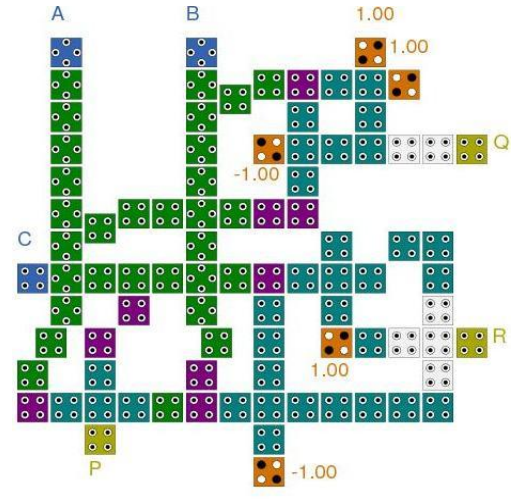

(b)

Figure 2. The Proposed URQG (a) Block Diagram (b) Cell Layout

Table 1. Truth Table of URQG Gate

\begin{tabular}{|c|c|c|c|c|c|}
\hline $\mathrm{A}$ & $\mathrm{B}$ & $\mathrm{C}$ & $\mathrm{P}$ & $\mathrm{Q}$ & $\mathrm{R}$ \\
\hline 0 & 0 & 0 & 1 & 1 & 0 \\
\hline 0 & 0 & 1 & 0 & 1 & 0 \\
\hline 0 & 1 & 0 & 1 & 0 & 0 \\
\hline 0 & 1 & 1 & 1 & 0 & 1 \\
\hline 1 & 0 & 0 & 0 & 0 & 1 \\
\hline 1 & 0 & 1 & 0 & 0 & 0 \\
\hline 1 & 1 & 0 & 1 & 1 & 1 \\
\hline 1 & 1 & 1 & 0 & 1 & 1 \\
\hline
\end{tabular}

The URQG gate is simulated using the QCADesigner tool. The simulation waveform of the proposed URQG gate is shown in Figure 3. It confirms that the proposed QCA 
layout has achieved the desired functionality with a latency of one. The proposed gate is compared with all the existing QCA reversible gates. The analysis of the results reported in Table 3 indicates that the proposed URQG gate QCA implementation is efficient in terms of the QCA design metrics. It requires eighty-nine QCA cells and a delay of one clock, which is effective for designing larger circuits. It also covers a minimum area of $0.09 \mu \mathrm{m}^{2}$. Comparison graph for this implementation is shown in Figure 4.

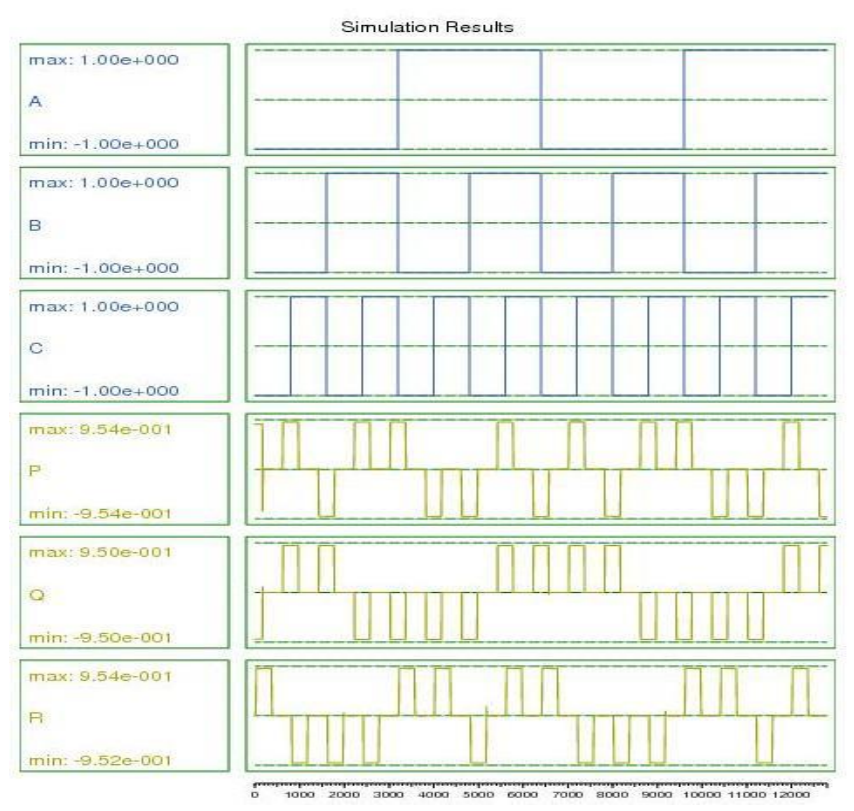

Figure 3. Simulation Results of the URQG Gate

Table 2. Comparison between the New URQG and the Existing Gates

\begin{tabular}{|l|l|l|l|l|l|}
\hline Thirteen standard functions & FRG [14] & PG [15] & $\begin{array}{l}\text { RUG } \\
{[\mathbf{1 6}]}\end{array}$ & $\begin{array}{l}\text { PPRG } \\
{[\mathbf{1 7}]}\end{array}$ & $\begin{array}{l}\text { Proposed } \\
\text { URQG }\end{array}$ \\
\hline Reversible/Nonreversible & Y/Y & Y/N & Y/N & Y/Y & Y/Y \\
\hline $\mathrm{ABC}$ & 2 & 2 & 2 & 2 & 2 \\
\hline $\mathrm{AB}$ & 1 & 1 & 1 & 1 & 1 \\
\hline $\mathrm{ABC}+\overline{\mathrm{ABC}}$ & 3 & 3 & 2 & 2 & 3 \\
\hline $\mathrm{ABC}+\mathrm{A} \overline{\mathrm{BC}}$ & 4 & 4 & 3 & 3 & 2 \\
\hline $\mathrm{AB}+\mathrm{BC}$ & 2 & 2 & 2 & 2 & 2 \\
\hline $\mathrm{ABC}+\overline{\mathrm{A}} \overline{\mathrm{B}} \mathrm{C}$ & 5 & 3 & 3 & 2 & 2 \\
\hline$\overline{\mathrm{A}} \mathrm{BC}+\overline{\mathrm{A}} \overline{\mathrm{BC}}+\mathrm{AB} \overline{\mathrm{C}}$ & 6 & 4 & 3 & 3 & 2 \\
\hline $\mathrm{A}$ & 1 & 1 & 1 & 1 & 1 \\
\hline $\mathrm{AB}+\mathrm{BC}+\mathrm{AC}$ & 5 & 4 & 1 & 2 & 2 \\
\hline $\mathrm{AB}+\overline{\mathrm{B} C}$ & 1 & 3 & 1 & 1 & 1 \\
\hline $\mathrm{AB}+\mathrm{BC}+\overline{\mathrm{ABC}}$ & 6 & 1 & 2 & 2 & 2 \\
\hline $\mathrm{AB}+\overline{\mathrm{A}} \overline{\mathrm{B}}$ & 2 & 1 & 1 & 2 & 1 \\
\hline $\mathrm{ABC}+\overline{\mathrm{A}} \overline{\mathrm{B} C}+\overline{\mathrm{ABC}}+\overline{\mathrm{A}} \overline{\mathrm{C} C}$ & 3 & 3 & 2 & 2 & 3 \\
\hline
\end{tabular}


Table 3. Comparison between Proposed Gate Layout and the Existing Gate Layout

\begin{tabular}{|l|l|l|l|l|}
\hline Reversible gates & $\begin{array}{l}\text { Cell } \\
\text { Count }\end{array}$ & $\begin{array}{l}\text { Area } \\
\left(\mu \mathrm{m}^{2}\right)\end{array}$ & Latency & $\begin{array}{l}\text { Total no. of gates } \\
\text { For 13 standard } \\
\text { Functions }(\mathrm{G})\end{array}$ \\
\hline TR [9] & 122 & 0.09 & 1 & 52 \\
\hline Fredkin [14] & 246 & 0.37 & 1 & 41 \\
\hline RUG [16] & 297 & 0.46 & 2 & 30 \\
\hline PPRG [17] & 171 & 0.19 & 1 & 25 \\
\hline QCA1 [18] & 147 & 0.16 & 0.5 & 29 \\
\hline RM [19] & 224 & 0.25 & 1 & 28 \\
\hline Reversible gate [20] & 90 & 0.09 & 1 & 26 \\
\hline URQG (proposed) & 88 & 0.09 & 1 & 24 \\
\hline
\end{tabular}

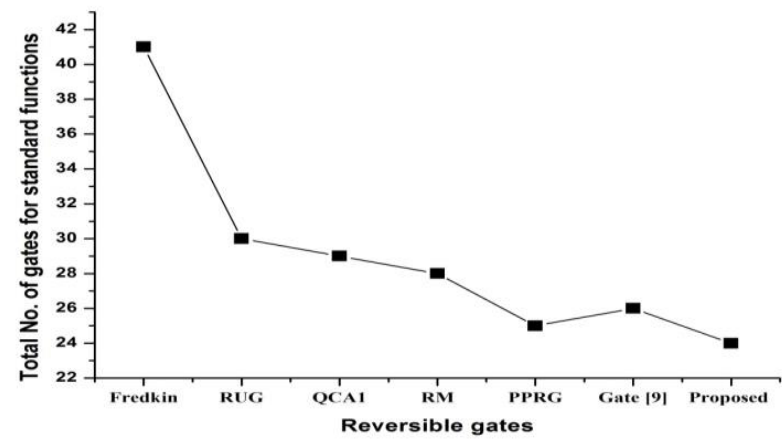

Figure 4. Comparison Graph for Implementing QCA Standard Functions

\subsection{Power Dissipation}

The total power dissipation of a QCA circuit is composed of two components: leakage and switching. The power losses during the clock alternations period and switching are termed as the leakage power and switching power, respectively [10]. In this section, a comprehensive power analysis and comparison of the proposed layout of the URQG with existing Fredkin gate [14], RM [21], PPRG [17] reversible gates are performed. The QCAPro tool is utilized as an adequate tool for estimating the power consumption of the structures at a $2 \mathrm{~K}$ temperature under three different tunneling energy levels $\left(0.5 \mathrm{E}_{\mathrm{k}}, 1.0 \mathrm{E}_{\mathrm{k}}\right.$, and $\left.1.5 \mathrm{E}_{\mathrm{k}}\right)$. The power dissipation map for the URQG gate implementation is shown in Figure 5. The cells with higher power dissipation are distinguished using thermal hotspots with darker colors. The average leakage and switching energy dissipation of the proposed URQG implementations and the previously proposed reversible gates are listed in Table 4. The power analysis results indicate a significant efficiency obtained by our URQG design for both the switching and leakage energy dissipation criteria.

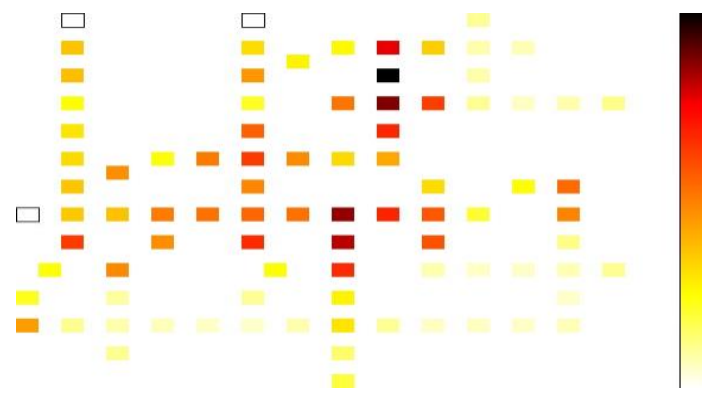

Figure 5. Power Dissipation Map of URQG Gate 
Table 4. Energy Dissipation Results

\begin{tabular}{|c|c|c|c|}
\hline \multirow[t]{2}{*}{ Design } & $\begin{array}{l}\text { Leakage energy } \\
\text { dissipation }(\mathrm{eV})\end{array}$ & $\begin{array}{l}\text { Switching energy } \\
\text { dissipation }(\mathrm{eV})\end{array}$ & $\begin{array}{l}\text { Total energy } \\
\text { dissipation }(\mathrm{eV})\end{array}$ \\
\hline & $0.5 \mathrm{E}_{\mathrm{k}} \quad 1.0 \mathrm{E}_{\mathrm{k}} \quad 1.5 \mathrm{E}_{\mathrm{k}}$ & $0.5 \mathrm{E}_{\mathrm{k}} 1.0 \mathrm{E}_{\mathrm{k}} 1.5 \mathrm{E}_{\mathrm{k}}$ & $0.5 \mathrm{E}_{\mathrm{k}} \quad 1.0 \mathrm{E}_{\mathrm{k}} 1.5 \mathrm{E}_{\mathrm{k}}$ \\
\hline Fredkin [14] & $\begin{array}{llll}0.101 & 0.283 & 0.482\end{array}$ & $\begin{array}{llll}0.213 & 0.175 & 0.143\end{array}$ & 0.3140 .4580 .625 \\
\hline PPRG [17] & $\begin{array}{lll}0.058 & 0.168 & 0.294\end{array}$ & $0.193 \quad 0.166 \quad 0.141$ & $\begin{array}{lll}0.251 & 0.334 & 0.435\end{array}$ \\
\hline RM [19] & $\begin{array}{lll}0.117 & 0.318 & 0.534\end{array}$ & $\begin{array}{llll}0.309 & 0.251 & 0.205\end{array}$ & $\begin{array}{lll}0.426 & 0.569 & 0.739\end{array}$ \\
\hline $\begin{array}{l}\text { New } \\
\text { (URQG) }\end{array}$ & $\begin{array}{llll}0.043 & 0.125 & 0.219\end{array}$ & $\begin{array}{llll}0.099 & 0.085 & 0.072\end{array}$ & $\begin{array}{lll}0.142 & 0.210 & 0.291\end{array}$ \\
\hline
\end{tabular}

\subsection{Fault Tolerance Analysis of URQG}

In this section, the fault tolerant analysis of the URQG gate is performed. During the manufacturing of QCA circuits, defects are likely to occur. These defects are mainly due to missing and additional QCA cells [14]. Faults have been injected into the gate to validate the fault tolerance of the proposed URQG gate. Any QCA layout can be easily converted to the equivalent hardware description language notations by using the HDLQ Verilog library [15]. The library consists of majority voter (MV), inverter (INV), crosswire (CW), fan out (FO) and L-shaped wire (LS) with fault injection capability. The fault set and defect impact of these standard QCA devices are defined in [14, 15]. In the QCA layout of XNOR gate which is used in the proposed URQG gate layout Q output, as shown in Figure 6a, two number of majority voters are used. In this structure, the two outputs of majority voters are connected to a single line to produce the desired output. If multiple inputs are connected to a single line, it is called Fan-in at the inputs. The fault set and HDLQ model of this Fan-in structured QCA devices are not defined previously. In this Section, the fault set of XNOR gate QCA device shown in Figure 6a is established, through extensive simulation and the impact of the defects is evaluated. Input and output cells are located outside the layout of the device and a single missing or additional cell deposition defect is injected either in the original device or along the adjacency boundary, i.e., no defect is injected for input/output cells. Figure $6 \mathrm{~b}$ shows the cell layout of the XNOR gate and the locations of the possible cell deposition defects.

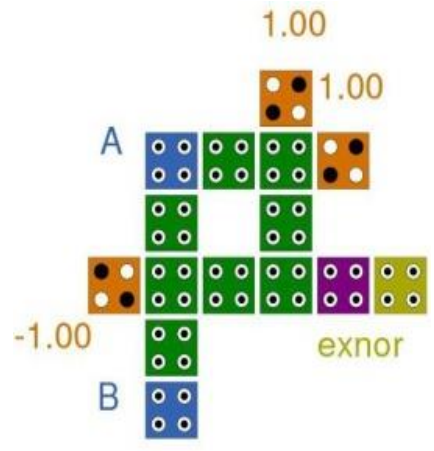

(a)

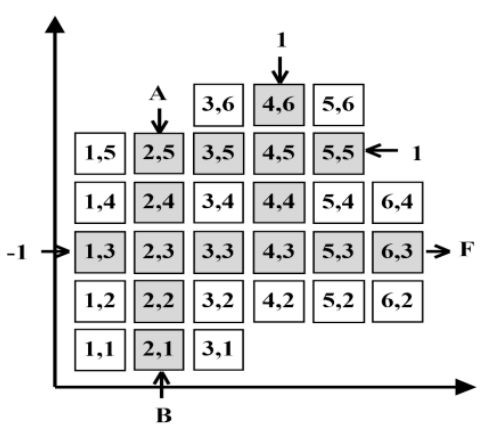

(b)

Figure 6. Ex-Nor Gate (a)QCA Layout (b) Cell Positions

The two coordinates are used to identify the position of cells in the cartesian layout. Simulation results are reported in Table $5 . \mathrm{C}_{M}$ shows the coordinates of the missing cell deposition defect; $\mathrm{C}_{\mathrm{A}}$ shows the coordinates of the extra cell deposition defect; Pmax denotes the highest magnitude polarization of $F$. This depicts the strength of the signal 
between the highest polarization (1) and an extremely low polarization (0). All input values are applied with maximum polarization.

Table 5. Functionality of XNOR Gate under Cell Deposition Defects

\begin{tabular}{|l|l|l|l|l|l|l|l|}
\hline $\mathrm{C}_{\mathrm{M}}$ & $\mathrm{F}$ & \multicolumn{2}{|l|}{ Polarization } & $\mathrm{C}_{\mathrm{A}}$ & $\mathrm{F}$ & \multicolumn{2}{l|}{ Polarization } \\
\hline & & $\mathrm{P}_{\max }$ & $\mathrm{P}_{\min }$ & & & $\mathrm{P}_{\max }$ & $\mathrm{P}_{\min }$ \\
\hline 1,3 & 1 & +0.95 & -0.81 & 1,1 & $\overline{\mathrm{A} \oplus \mathrm{B}}$ & +0.95 & -0.95 \\
\hline 2,1 & $\overline{\mathrm{A}}$ & +0.95 & -0.95 & 1,2 & $\overline{\mathrm{A}}+\mathrm{B}$ & +0.95 & -0.95 \\
\hline 2,2 & - & - & - & 1,4 & $\overline{\mathrm{A} \oplus \mathrm{B}}$ & +0.95 & -0.95 \\
\hline 2,3 & 1 & +0.98 & +0.38 & 1,5 & $\overline{\mathrm{A} \oplus \mathrm{B}}$ & +0.95 & -0.95 \\
\hline 2,4 & 0 & +0.36 & -0.95 & 2,6 & $\overline{\mathrm{A} \oplus \mathrm{B}}$ & +0.95 & -0.95 \\
\hline 2,5 & 0 & +0.30 & -0.95 & 3,1 & $\overline{\mathrm{A} \oplus \mathrm{B}}$ & +0.95 & -0.95 \\
\hline 3,3 & 1 & +0.95 & -0.89 & 3,2 & $\mathrm{~A}+\mathrm{B}$ & +0.95 & -0.95 \\
\hline 3,5 & $\overline{\mathrm{A} \oplus \mathrm{B}}$ & +0.95 & -0.95 & 3,4 & $\mathrm{~A}$ & +0.95 & -0.98 \\
\hline 4,3 & 0 & +0.37 & -0.95 & 3,6 & $\overline{\mathrm{A} \oplus \mathrm{B}}$ & +0.95 & -0.95 \\
\hline 4,4 & 0 & +0.24 & -0.95 & 4,2 & $\overline{\mathrm{A}}+\mathrm{B}$ & +0.95 & -0.95 \\
\hline 4,5 & 0 & +0.25 & -0.95 & 4,7 & $\overline{\mathrm{A} \oplus \mathrm{B}}$ & +0.95 & -0.95 \\
\hline 4,6 & $\mathrm{AB}$ & +0.95 & -0.95 & 5,2 & $\overline{\mathrm{A} \oplus \mathrm{B}}$ & +0.94 & -0.94 \\
\hline 5,3 & - & - & - & 5,4 & 1 & +0.95 & -0.53 \\
\hline 5,5 & $\overline{\mathrm{A} \oplus \mathrm{B}}$ & +0.95 & -0.95 & 5,6 & $\overline{\mathrm{A} \oplus \mathrm{B}}$ & +0.95 & -0.95 \\
\hline 6,3 & $\overline{\mathrm{A} \oplus \mathrm{B}}$ & +0.95 & -0.95 & 6,2 & $\overline{\mathrm{A} \oplus \mathrm{B}}$ & +0.98 & -0.98 \\
\hline & & & & 6,4 & $\overline{\mathrm{A} \oplus \mathrm{B}}$ & +0.98 & -0.98 \\
\hline
\end{tabular}

From Table 5 it is found that total six number of faults are possible by both single missing cell and additional cell deposition defects These six fault sets are $\left\{1, A^{\prime}, 0, A B\right.$, $\left.\left(\mathrm{A}^{\prime}+\mathrm{B}\right), \mathrm{A}\right\}$. In this work, we proposed a new HDLQ model of XNOR logic having this fault set. The HDLQ model design of the proposed URQG gate is shown in Figure 7. The model contains 21 elements $(\mathrm{MV}=4, \mathrm{INV}=4, \mathrm{CW}=3, \mathrm{FO}=6, \mathrm{LS}=3$, proposed XNOR HDLQ model=1). An exhaustive testing is conducted for this model using eight input test vectors in the presence of all the possible missing or additional cell defects in MV, INV, $\mathrm{CW}, \mathrm{FO}, \mathrm{LS}$, and proposed XNOR block. The number of fault patterns for MV, INV, CW, FO, LS, proposed XNOR block are 2,1,2,1,1,6 respectively [14, 15]. The design is simulated using Verilog HDL simulator which generates a total of 33 fault patterns, of which 26 fault patterns are unique for all the blocks, as shown in Table 6 . In Table $6, a_{i}$ is a three-bit number with an equivalent decimal value of $i$. For example, a 6 represents 110 (i.e., decimal 6). It is evident from Table 6 that for test vector $\mathrm{a}_{3}$, the proposed gate exhibits the highest fault tolerance capability of $61 \%$. It also exhibits an overall fault tolerance capability of $51.12 \%$ for all the test vectors, which indicates there is an average of $51.12 \%$ successful patterns that produce the correct output, even when there is a fault. 


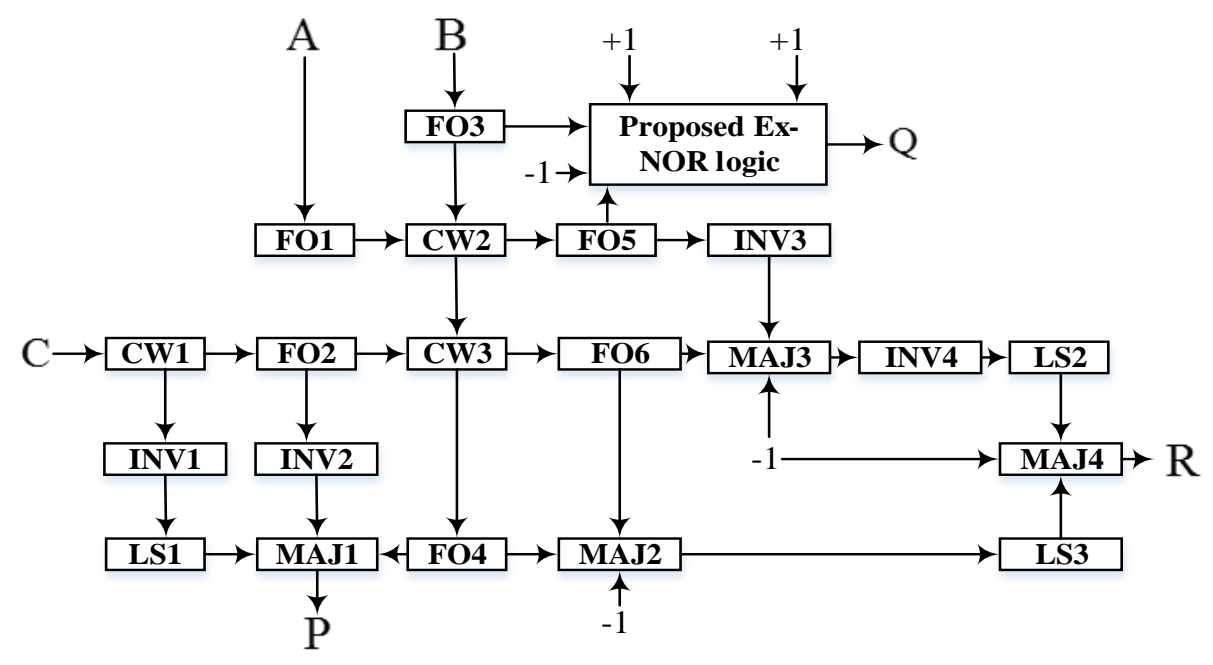

Figure 7. HDLQ Model of URQG Gate

Table 6. Fault Patterns in URQG

\begin{tabular}{|c|c|c|c|c|c|c|c|c|c|c|c|c|c|c|c|c|c|}
\hline IV & EV & 1 & 2 & 3 & 4 & 5 & 6 & 7 & 8 & 9 & 10 & 11 & 12 & 13 & 14 & 15 & 16 \\
\hline $\mathrm{a}_{0}$ & $\mathrm{a}_{6}$ & $\mathrm{a}_{2}$ & $\mathrm{a}_{2}$ & $\mathrm{a}_{6}$ & $\mathrm{a}_{5}$ & $\mathrm{a}_{6}$ & $\mathrm{a}_{5}$ & $\mathrm{a}_{6}$ & $\mathrm{a}_{4}$ & $\mathrm{a}_{6}$ & $\mathrm{a}_{7}$ & $\mathrm{a}_{6}$ & $\mathrm{a}_{2}$ & $\mathrm{a}_{7}$ & $\mathrm{a}_{7}$ & $\mathrm{a}_{6}$ & $\mathrm{a}_{6}$ \\
\hline $\mathrm{a}_{1}$ & $\mathrm{a}_{2}$ & $\mathrm{a}_{2}$ & $\mathrm{a}_{2}$ & $\mathrm{a}_{7}$ & $\mathrm{a}_{0}$ & $\mathrm{a}_{2}$ & $\mathrm{a}_{0}$ & $\mathrm{a}_{2}$ & $\mathrm{a}_{0}$ & $\mathrm{a}_{3}$ & $\mathrm{a}_{2}$ & $\mathrm{a}_{2}$ & $\mathrm{a}_{6}$ & $\mathrm{a}_{3}$ & $\mathrm{a}_{3}$ & $\mathrm{a}_{6}$ & $\mathrm{a}_{6}$ \\
\hline $\mathrm{a}_{2}$ & $\mathrm{a}_{4}$ & $\mathrm{a}_{4}$ & $\mathrm{a}_{5}$ & $\mathrm{a}_{4}$ & $\mathrm{a}_{4}$ & $\mathrm{a}_{4}$ & $\mathrm{a}_{7}$ & $\mathrm{a}_{5}$ & $\mathrm{a}_{6}$ & $\mathrm{a}_{4}$ & $\mathrm{a}_{5}$ & $\mathrm{a}_{4}$ & $\mathrm{a}_{4}$ & $\mathrm{a}_{5}$ & $\mathrm{a}_{5}$ & $\mathrm{a}_{0}$ & $\mathrm{a}_{4}$ \\
\hline $\mathrm{a}_{3}$ & $\mathrm{a}_{5}$ & $\mathrm{a}_{1}$ & $\mathrm{a}_{5}$ & $\mathrm{a}_{0}$ & $\mathrm{a}_{5}$ & $\mathrm{a}_{4}$ & $\mathrm{a}_{7}$ & $\mathrm{a}_{4}$ & $\mathrm{a}_{7}$ & $\mathrm{a}_{4}$ & $\mathrm{a}_{5}$ & $\mathrm{a}_{5}$ & $\mathrm{a}_{5}$ & $\mathrm{a}_{5}$ & $\mathrm{a}_{4}$ & $\mathrm{a}_{5}$ & $\mathrm{a}_{5}$ \\
\hline $\mathrm{a}_{4}$ & $\mathrm{a}_{1}$ & $\mathrm{a}_{5}$ & $\mathrm{a}_{1}$ & $\mathrm{a}_{5}$ & $\mathrm{a}_{1}$ & $\mathrm{a}_{0}$ & $\mathrm{a}_{2}$ & $\mathrm{a}_{0}$ & $\mathrm{a}_{3}$ & $\mathrm{a}_{1}$ & $\mathrm{a}_{0}$ & $\mathrm{a}_{0}$ & $\mathrm{a}_{1}$ & $\mathrm{a}_{0}$ & $\mathrm{a}_{1}$ & $\mathrm{a}_{1}$ & $\mathrm{a}_{1}$ \\
\hline $\mathrm{a}_{5}$ & $\mathrm{a}_{0}$ & $\mathrm{a}_{0}$ & $\mathrm{a}_{1}$ & $\mathrm{a}_{1}$ & $\mathrm{a}_{0}$ & $\mathrm{a}_{0}$ & $\mathrm{a}_{2}$ & $\mathrm{a}_{1}$ & $\mathrm{a}_{2}$ & $\mathrm{a}_{1}$ & $\mathrm{a}_{0}$ & $\mathrm{a}_{1}$ & $\mathrm{a}_{0}$ & $\mathrm{a}_{1}$ & $\mathrm{a}_{1}$ & $\mathrm{a}_{4}$ & $\mathrm{a}_{0}$ \\
\hline $\mathrm{a}_{6}$ & $\mathrm{a}_{7}$ & $\mathrm{a}_{7}$ & $\mathrm{a}_{7}$ & $\mathrm{a}_{3}$ & $\mathrm{a}_{4}$ & $\mathrm{a}_{7}$ & $\mathrm{a}_{4}$ & $\mathrm{a}_{7}$ & $\mathrm{a}_{5}$ & $\mathrm{a}_{7}$ & $\mathrm{a}_{6}$ & $\mathrm{a}_{6}$ & $\mathrm{a}_{3}$ & $\mathrm{a}_{6}$ & $\mathrm{a}_{7}$ & $\mathrm{a}_{3}$ & $\mathrm{a}_{3}$ \\
\hline $\mathrm{a}_{7}$ & $\mathrm{a}_{3}$ & $\mathrm{a}_{7}$ & $\mathrm{a}_{7}$ & $\mathrm{a}_{2}$ & $\mathrm{a}_{1}$ & $\mathrm{a}_{3}$ & $\mathrm{a}_{1}$ & $\mathrm{a}_{3}$ & $\mathrm{a}_{1}$ & $\mathrm{a}_{2}$ & $\mathrm{a}_{3}$ & $\mathrm{a}_{3}$ & $\mathrm{a}_{7}$ & $\mathrm{a}_{3}$ & $\mathrm{a}_{2}$ & $\mathrm{a}_{3}$ & $\mathrm{a}_{3}$ \\
\hline
\end{tabular}

\begin{tabular}{|c|c|c|c|c|c|c|c|c|c|c|}
\hline 17 & 18 & 19 & 20 & 21 & 22 & 23 & 24 & 25 & 26 & FT \\
\hline $\mathrm{a}_{7}$ & $\mathrm{a}_{6}$ & $\mathrm{a}_{7}$ & $\mathrm{a}_{7}$ & $\mathrm{a}_{4}$ & $\mathrm{a}_{6}$ & $\mathrm{a}_{4}$ & $\mathrm{a}_{4}$ & $\mathrm{a}_{6}$ & $\mathrm{a}_{6}$ & $42 \%$ \\
\hline $\mathrm{a}_{2}$ & $\mathrm{a}_{2}$ & $\mathrm{a}_{3}$ & $\mathrm{a}_{3}$ & $\mathrm{a}_{0}$ & $\mathrm{a}_{2}$ & $\mathrm{a}_{0}$ & $\mathrm{a}_{0}$ & $\mathrm{a}_{2}$ & $\mathrm{a}_{2}$ & $42 \%$ \\
\hline $\mathrm{a}_{5}$ & $\mathrm{a}_{5}$ & $\mathrm{a}_{5}$ & $\mathrm{a}_{5}$ & $\mathrm{a}_{6}$ & $\mathrm{a}_{4}$ & $\mathrm{a}_{4}$ & $\mathrm{a}_{4}$ & $\mathrm{a}_{4}$ & $\mathrm{a}_{6}$ & $46 \%$ \\
\hline $\mathrm{a}_{5}$ & $\mathrm{a}_{5}$ & $\mathrm{a}_{5}$ & $\mathrm{a}_{5}$ & $\mathrm{a}_{7}$ & $\mathrm{a}_{5}$ & $\mathrm{a}_{5}$ & $\mathrm{a}_{5}$ & $\mathrm{a}_{5}$ & $\mathrm{a}_{7}$ & $61 \%$ \\
\hline $\mathrm{a}_{1}$ & $\mathrm{a}_{1}$ & $\mathrm{a}_{1}$ & $\mathrm{a}_{1}$ & $\mathrm{a}_{1}$ & $\mathrm{a}_{1}$ & $\mathrm{a}_{1}$ & $\mathrm{a}_{1}$ & $\mathrm{a}_{3}$ & $\mathrm{a}_{3}$ & $57 \%$ \\
\hline $\mathrm{a}_{0}$ & $\mathrm{a}_{0}$ & $\mathrm{a}_{0}$ & $\mathrm{a}_{1}$ & $\mathrm{a}_{0}$ & $\mathrm{a}_{0}$ & $\mathrm{a}_{0}$ & $\mathrm{a}_{0}$ & $\mathrm{a}_{2}$ & $\mathrm{a}_{2}$ & $50 \%$ \\
\hline $\mathrm{a}_{7}$ & $\mathrm{a}_{7}$ & $\mathrm{a}_{7}$ & $\mathrm{a}_{7}$ & $\mathrm{a}_{7}$ & $\mathrm{a}_{7}$ & $\mathrm{a}_{7}$ & $\mathrm{a}_{5}$ & $\mathrm{a}_{5}$ & $\mathrm{a}_{7}$ & $54 \%$ \\
\hline $\mathrm{a}_{3}$ & $\mathrm{a}_{3}$ & $\mathrm{a}_{3}$ & $\mathrm{a}_{3}$ & $\mathrm{a}_{3}$ & $\mathrm{a}_{3}$ & $\mathrm{a}_{3}$ & $\mathrm{a}_{1}$ & $\mathrm{a}_{1}$ & $\mathrm{a}_{3}$ & $57 \%$ \\
\hline
\end{tabular}

$\mathrm{IV}=$ input vectors, $\mathrm{EV}=$ expected vectors, $\mathrm{FT}=$ fault tolerance in $\%$, Average fault tolerance $=51.12 \%$

\section{The Proposed Architecture of Reversible Comparator}

By combining two URQG gates, a reversible one-bit comparator can be efficiently designed as shown in Figure 8a. In this circuit has two constant inputs and three garbage outputs. The QCA layout and simulation results of the proposed one-bit reversible comparator are shown in Figure $8 b$ and Figure $8 c$, respectively. From the simulation results, it is evident that the delay is 0.75 clocks. This reduced delay is possible because of both the proposed gates in the comparator function independently and the output $\mathrm{R}$ is not used in the comparator structure. 
(a)
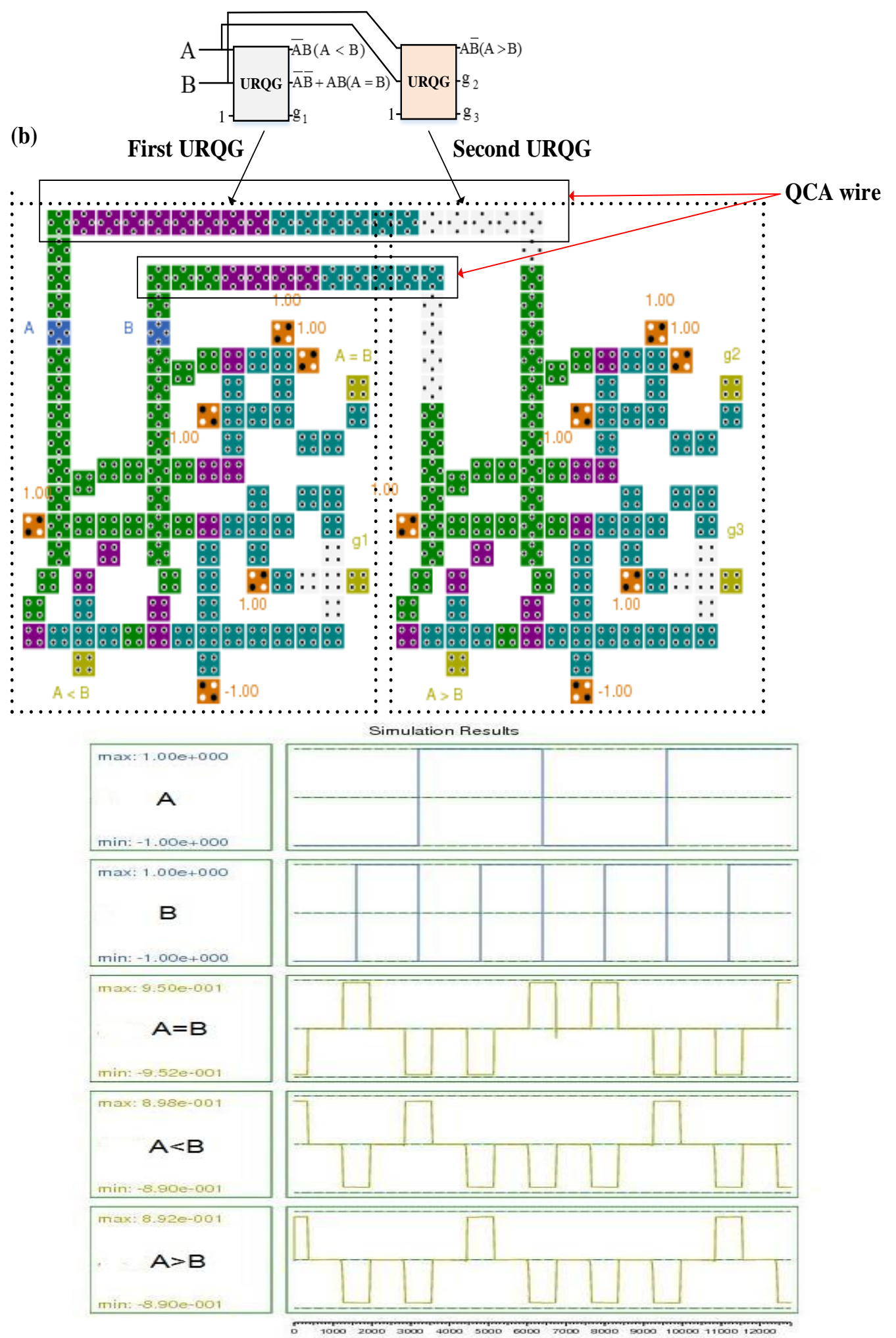

(c)

Figure 8. One-bit Reversible Comparator (a) Block Diagram (b) QCA Layout (c) Simulation Result 
Table 7 compares the existing one-bit reversible QCA comparator [6] with the proposed one-bit comparator. The proposed comparator structure can be extended to any number of bits (i.e., n). Accordingly, a proposed one-bit comparator cell is designed. This cell compares the outputs of the previous stage with the current inputs and produces three outputs. In a one-bit comparator cell, five URQG gates and two Feynman gates are used, wherein the latter is employed for the addition of two input numbers. The structure of a two-bit reversible comparator using a one-bit comparator and a one-bit comparator cell is shown in Figure 9a. Further, the first stage produces the output of the comparison of the two most significant bits (MSB) of the inputs A and B. The second stage is a one-bit comparator cell, which compares the outputs of the first stage with $\mathrm{A}_{0}$ and $\mathrm{B}_{0}$ and presents the final results. The Boolean expressions for the two-bit comparator are shown by equation (1) to (3).

$$
\begin{aligned}
& (\mathrm{A}<\mathrm{B})=\left(\mathrm{A}_{\mathrm{n}-1}<\mathrm{B}_{\mathrm{n}-1}\right)+\left(\mathrm{A}_{\mathrm{n}-1}=\mathrm{B}_{\mathrm{n}-1}\right) \times\left(\mathrm{A}_{\mathrm{n}-2}<\mathrm{B}_{\mathrm{n}-2}\right), \\
& (\mathrm{A}>\mathrm{B})=\left(\mathrm{A}_{\mathrm{n}-1}>\mathrm{B}_{\mathrm{n}-1}\right)+\left(\mathrm{A}_{\mathrm{n}-1}=\mathrm{B}_{\mathrm{n}-1}\right) \times\left(\mathrm{A}_{\mathrm{n}-2}>\mathrm{B}_{\mathrm{n}-2}\right), \\
& (\mathrm{A}=\mathrm{B})=(\mathrm{A}<\mathrm{B}) \text { xnor }(\mathrm{A}>\mathrm{B}) .
\end{aligned}
$$

The general structure of the n-bit comparator structure is shown in Figure 9b. It is shown that for a comparator structure of size $\mathrm{n}$ bits, a one-bit comparator and (n-1) number of one-bit comparator cells is needed. In Figure 10, QCA layout of 2-bit comparator is illustrated. It requires 1302 cells with an area of $2 \mu \mathrm{m}^{2}$. The QCA design analysis of n-bit comparator structure is detailed in Table 8 .

\section{1-bit comparator}

1-bit comparator cell

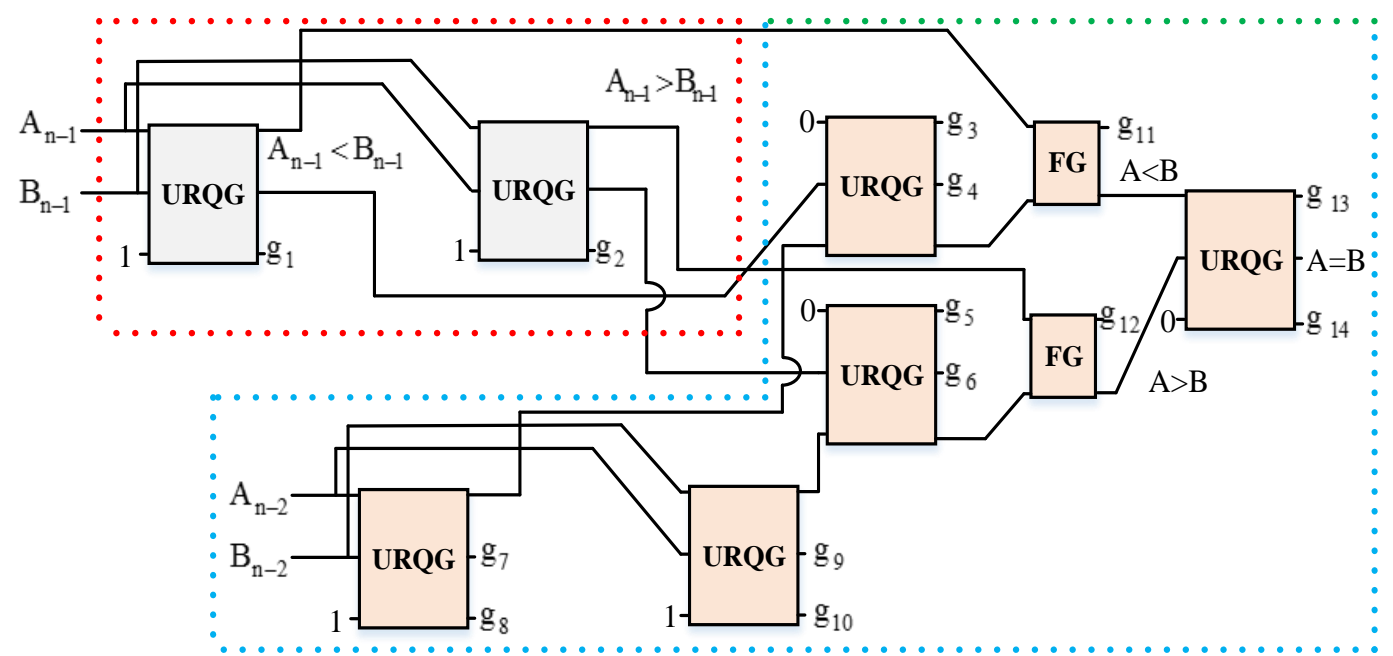

(a)

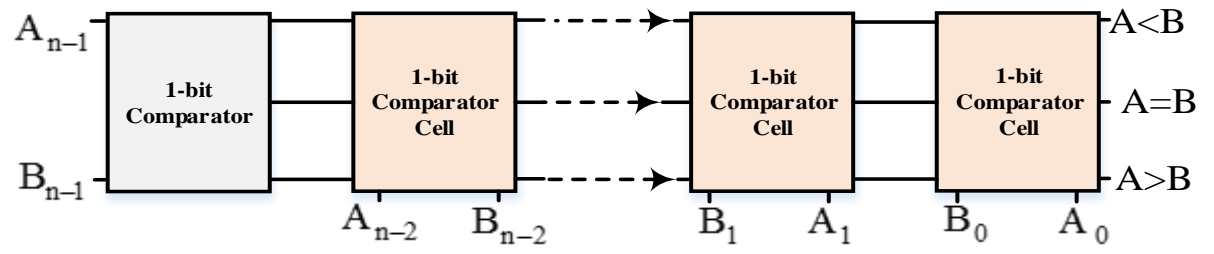

(b)

Figure 9. The Proposed Design of Reversible Comparator (a) 2-bit (b) n-bit 


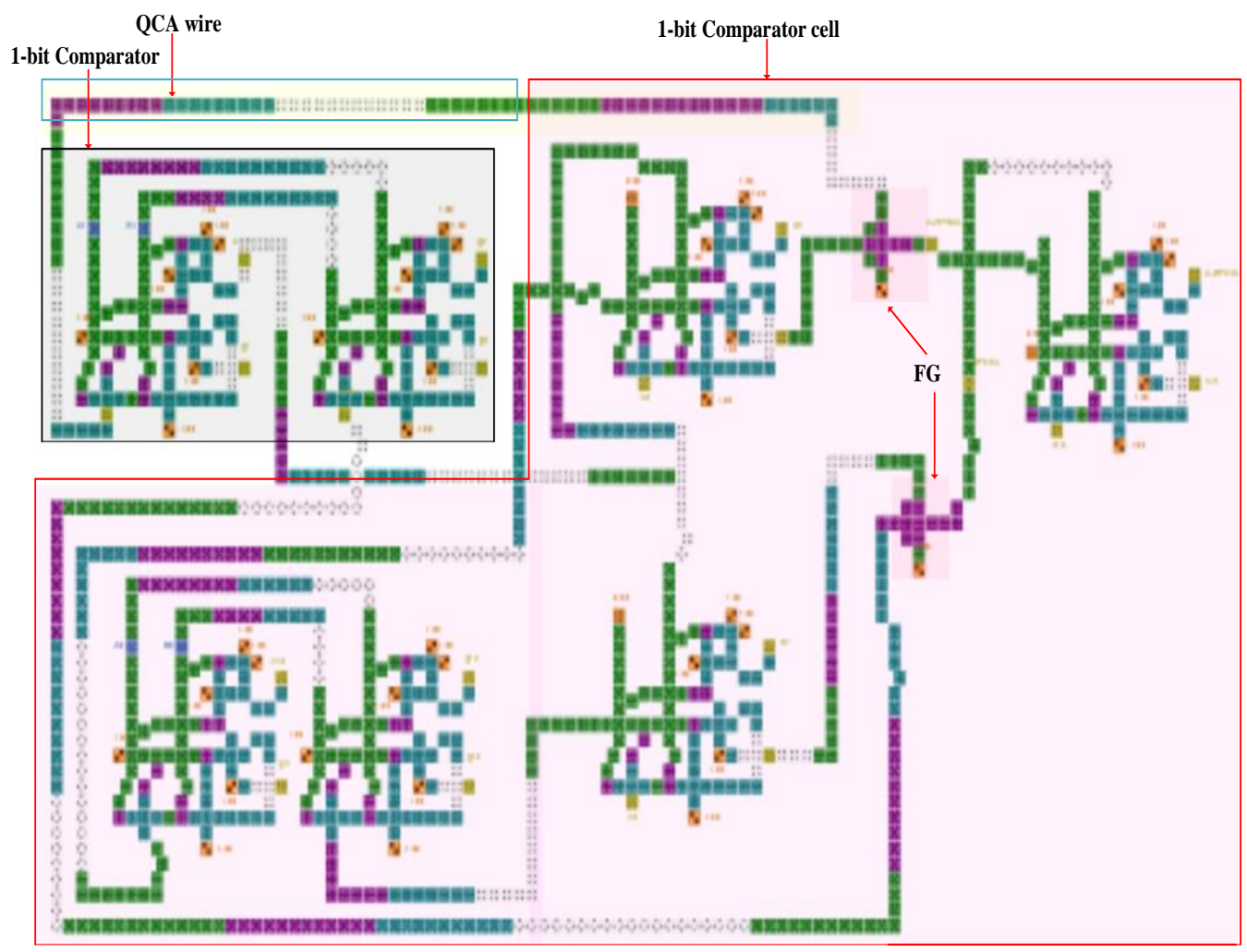

Figure 10. QCA Layout of 2-bit Reversible Comparator Structure

\section{Comparision Results and Discussion}

The cost comparison has been developed by the proposed layout of the 1-bit reversible comparator and the optimized primitives results have been calculated. The results from the proposed methodology of the layout are in good agreement with the targeted results. Thus the constructed layout of these designs is validated by the simulation result and thus the complexity meet the current nanoelectronics application. The complexity of proposed 1-bit comparator is $31.03 \%$ less compare to [9]. We can compute the area is $0.23 \mu \mathrm{m}^{2}$ (32.35\%) less than [9], similarly for present layout latency is $0.75(75 \%)$ less than existing design in [9]. Hence it can be said this design of 1-bit reversible comparator is giving compact layout and minimum latency as compared to existing work in [9]. This result is really interesting and encouraging. Table 8 show different size order comparator results in terms of gate used majority gate, the number of the inverter, and area.

Table 7. Cost Comparison of Proposed 1-bit Reversible Comparator

\begin{tabular}{|c|c|c|c|c|}
\hline Design & $\begin{array}{c}\text { Cell } \\
\text { Count }\end{array}$ & $\begin{array}{c}\text { Area } \\
\left(\mu \mathrm{m}^{2}\right)\end{array}$ & Latency & $\begin{array}{c}\text { Quantum cost [6] } \\
\text { Areax Latency }^{2}\end{array}$ \\
\hline Existing [9] & 319 & 0.34 & 3.0 & 3.087 \\
\hline Proposed & 220 & 0.23 & 0.75 & 0.129 \\
\hline $\begin{array}{c}\text { Improvement in \% over } \\
{[9]}\end{array}$ & $31.03 \%$ & $32.35 \%$ & $75 \%$ & $95.82 \%$ \\
\hline
\end{tabular}


Table 8. QCA Structure Analysis of $\mathbf{n}$-bit reversible Comparators

\begin{tabular}{|l|l|l|l|l|l|}
\hline Design & $\begin{array}{l}\text { No. of } \\
\text { URQG } \\
\text { gates }\end{array}$ & $\begin{array}{l}\text { No. of } \\
\text { FG }\end{array}$ & No. of majority voters & $\begin{array}{l}\text { No. of } \\
\text { inverters }\end{array}$ & Total Area \\
\hline $\begin{array}{l}\text { 1-bit } \\
\text { comparator } \\
\text { cell }\end{array}$ & 5 & 2 & 34 & 20 & $2.01 \mu \mathrm{m}^{2}$ \\
\hline $\begin{array}{l}\text { 1-bit reversible } \\
\text { comparator }\end{array}$ & 2 & 0 & 12 & 08 & $0.129 \mu \mathrm{m}^{2}$ \\
\hline $\begin{array}{l}\text { 2-bit reversible } \\
\text { comparator }\end{array}$ & 7 & 2 & 46 & 28 & $2.05 \mu \mathrm{m}^{2}$ \\
\hline $\begin{array}{l}\text { 3-bit reversible } \\
\text { comparator }\end{array}$ & 12 & 4 & 80 & 48 & $4.15 \mu \mathrm{m}^{2}$ \\
\hline $\begin{array}{l}\text { 4- bit } \\
\text { reversible } \\
\text { comparator }\end{array}$ & 17 & 6 & 114 & 68 & $6.22 \mu \mathrm{m}^{2}$ \\
\hline $\begin{array}{l}\text { n-bit reversible } \\
\text { comparator }\end{array}$ & $5 \times(\mathrm{n}-1)+2$ & $\begin{array}{l}2 \times(\mathrm{n}- \\
1)\end{array}$ & $\begin{array}{l}6 \times(5 \times(\mathrm{n}-1)+2)+2 \times 2(\mathrm{n}- \\
1)\end{array}$ & $4 \times(5 \times(\mathrm{n}-1)+2)$ & - \\
\hline
\end{tabular}

\section{Conclusion}

In this work, we have described a 1-bit reversible comparator in QCA that uses a replica of URQG layout to design construction. This layout of 1-comparator again cascaded to 1-bit comparator cell layout to the construction of 2-bit comparator. The QCA wire is used to join this two layout and perform the required logic computation. We also showed that generic n-bit comparator architecture that was used some proposed modules cells to synthesize architecture. However, it has achieved in the layout design of 1-bit and 2-bit comparator that requires 220 cell count, and $2.05 \mu \mathrm{m}^{2}$ area on average. The use of reversible technology in combination with QCA, i.e., reversible-QCA comparator seems to be an attractive solution for future nanoelectronics systems.

\section{Acknowledgment}

This work was supported by Technical Education Quality Improvement Programme of Government of India.

\section{Conflict of Interest}

The authors declare that there is no conflict of interest regarding the publication of this article.

\section{References}

[1] N. Kumar Misra, B. Sen and S. Wairya, "Towards designing efficient reversible binary code converters and a dual-rail checker for emerging nanocircuits", Journal of Computational Electronics, vol. 16, no. 2 (2017), pp. 442-458.

[2] B. Sen, M. Dutta, S. Some and B. K. Sikdar, "Realizing reversible computing in QCA framework resulting in efficient design of testable ALU", ACM Journal on Emerging Technologies in Computing Systems (JETC), vol. 11, no. 3, (2014), pp. 30.

[3] C. H. Bennett, "Logical reversibility of computation", IBM journal of Research and Development, vol. 17, no. 6, (1973), pp. 525-532.

[4] M. Mohammadi, S. Gorgin and M. Mohammadi, "Design of non-restoring divider in quantum-dot cellular automata technology", IET Circuits, Devices \& Systems, vol. 11, no. 2, (2017), pp. 135-141.

[5] S. Angizi, M. Hossein Moaiyeri, S. Farrokhi, K. Navi and N. Bagherzadeh, "Designing quantum-dot cellular automata counters with energy consumption analysis", Microprocessors and Microsystems, vol. 39, no. 7, (2015), pp. 512-520. 
[6] A. Bose and A. Sarker, "A novel approach for constructing reversible fault tolerant n-bit binary comparator", In Informatics, Electronics \& Vision (ICIEV), 2014 International Conference, IEEE, (2014), pp. 1-6.

[7] H. G. Rangaraju, V. Hegde, K. B. Raja and K. N. Muralidhara, "Design of efficient reversible binary comparator", Procedia Engineering, vol. 30, (2012), pp. 897-904.

[8] H. Md Hasan Babu, N. Saleheen, L. Jamal, S. Muhammad Sarwar and T. Sasao, "Approach to design a compact reversible low power binary comparator", IET Computers \& Digital Techniques, vol. 8, no. 3 (2014), pp. 129-139.

[9] J. Chandra Das and D. De, "Reversible comparator design using quantum dot-cellular automata", IETE Journal of Research, vol. 62, no. 3, (2016), pp. 323-330.

[10] N. Kumar Misra, B. Sen and S. Wairya, "Designing conservative reversible n-bit binary comparator for emerging quantum-dot cellular automata nano circuits", Journal of Nanoengineering and Nanomanufacturing, vol. 6, no. 3, (2016), pp. 201-216.

[11] H. Thapliyal, N. Ranganathan and R. Ferreira, "Design of a comparator tree based on reversible logic", In Nanotechnology (IEEE-NANO), 2010 10th IEEE Conference, IEEE, (2010), pp. 1113-1116.

[12] M. Kianpour and R. Sabbaghi-Nadooshan, "Novel design of n-bit controllable inverter by Quantum-dot Cellular Automata", International Journal of Nanoscience and Nanotechnology, vol. 10, no. 2, (2014), pp. 117-126.

[13] C. Vudadha, P. Sai Phaneendra, V. Sreehari, S. Ershad Ahmed, N. Moorthy Muthukrishnan and M. B. Srinivas, "Design of prefix-based optimal reversible comparator", In VLSI (ISVLSI), 2012 IEEE Computer Society Annual Symposium, IEEE, (2012) August 19.

[14] E. Fredkin and T. Toffoli, "Conservative logic", Collision-based computing, vol. 1, (2002), pp. 47-81.

[15] A. Peres, "Reversible logic and quantum computers", Physical review A, vol. 32, no. 6, (1985), pp. 3266.

[16] K. Das, D. De and M. De, "Competent universal reversible logic gate design for quantum dot cellular automata", WSEAS Trans. Circuits System, vol. 11, (2012), pp. 401-411.

[17] A. Roohi, R. Zand, S. Angizi and R. F. Demara, "A Parity-Preserving Reversible QCA Gate with SelfChecking Cascadable Resiliency", IEEE Transactions on emerging topics in computing, (2016).

[18] X. Ma, J. Huang, C. Metra and F. Lombardi, "Reversible gates and testability of one dimensional arrays of molecular QCA", Journal of Electronic Testing, vol. 24, no. 1-3, (2008), pp. 297-311.

[19] B. Sen, M. Dutta, M. Goswami and B. K. Sikdar, "Modular Design of testable reversible ALU by QCA multiplexer with increase in programmability", Microelectronics Journal, vol. 45, no. 11, (2014), pp. $1522-1532$.

[20] A. Mokhtar Chabi, A. Roohi, H. Khademolhosseini, S. Sheikhfaal, S. Angizi, K. Navi and R. F. DeMara, "Towards ultra-efficient QCA reversible circuits", Microprocessors and Microsystems, vol. 49, (2017), pp. 127-138.

[21] B. Sen, D. Saran, M. Saha and B. K. Sikdar, "Synthesis of reversible universal logic around QCA with online testability”, In Electronic System Design (ISED), 2011 International Symposium, IEEE, pp. 236241, (2011), December 19.

[22] M. Momenzadeh, M. Ottavi and F. Lombardi, "Modeling QCA defects at molecular-level in combinational circuits", In Defect and Fault Tolerance in VLSI Systems, 2005. DFT 2005. 20th IEEE International Symposium, IEEE, (2005) October 3, pp. 208-216.

[23] M. Ottavi, L. Schiano, F. Lombardi and D. Tougaw, "HDLQ: a HDL environment for QCA design", ACM Journal on Emerging Technologies in Computing Systems (JETC), vol. 2, no. 4, (2006), pp. 243261. 
International Journal of Grid and Distributed Computing

Vol. 10, No. 9 (2017) 